\title{
Bibliometric analysis of the top 100 most cited articles on multimorbidity using the Dimensions database
}

\author{
FILIPE PRAZERES ${ }^{1-3, A-F}$, LÍGIA PASSOS ${ }^{4, \text { A-F }}$ \\ ORCID: 0000-0002-2849-5194 ORCID: 0000-0002-0659-5258 \\ ${ }^{1}$ Faculty of Health Sciences, University of Beira Interior, Covilhã, Portugal \\ ${ }^{2}$ Family Health Unit Beira Ria, Gafanha da Nazaré, Portugal \\ ${ }^{3}$ CINTESIS - Center for Health Technology and Services Research, Porto, Portugal \\ ${ }^{4}$ Department of Education and Psychology, University of Aveiro, Aveiro, Portugal
}

A - Study Design, B - Data Collection, C - Statistical Analysis, D - Data Interpretation, E - Manuscript Preparation, F - Literature Search, G - Funds Collection

Summary Background. Publications on multimorbidity have been significantly increasing in the last few years, as the interest and importance of $\mathrm{MM}$ become an emerging priority.

Objectives. To identify the 100 most-cited articles on multimorbidity in the new scholarly search database Dimensions and to analyse their features.

Material and methods. An online search was performed using the keywords "multimorbidity" and "multi-morbidity", combined with the Boolean operator "OR", from inception until 3 July 2019. The results were organised by order of number of citations, and the 100 most cited articles were selected after a critical reading of the abstract. Some data was collected from each included article: journal of publication, quartile and impact factor, year of publication, first author's name, country of origin, number of total and recent citations, Altmetric Attention Score and more.

Results. The number of citations ranged from 2,056 to 74. The 100 most-cited articles were published between 1996 and 2016, and more than half were published after 2010. They were classified as original research $(n=65)$, reviews $(n=24)$, perspective/opinion/ /commentary $(n=10)$ and position statement $(n=1)$. All articles were written in English and published in 48 journals -10 of those represented $53 \%$ of the articles published, and $61.1 \%$ the total of citations. 93 articles were published in first quartile journals. 70 articles were published in Open Access format.

Conclusions. The total number of citations was 19,777. Identification of articles with the most academic reach and influence will assist in generating evidence-based descriptions, comparisons and visualisation of research output on multimorbidity.

Key words: multimorbidity, bibliometrics, primary health care, publishing, database.

Prazeres F, Passos L. Bibliometric analysis of the top 100 most cited articles on multimorbidity using the Dimensions database. Fam Med Prim Care Rev 2021; 23(1): 49-58, doi: https://doi.org/10.5114/fmpcr.2021.101023.

\section{Background}

Multimorbidity (MM) is defined as "the complex interactions of several co-existing diseases" by the National Library of Medicine (NLM) controlled vocabulary thesaurus used for indexing articles for PubMed (https://www.ncbi.nlm.nih.gov/pubmed), and multimorbidity has been a Medical Subject Headings (MeSH) term since January 2018 [1]. MM also implies that no single disease holds priority over any of the co-occurring diseases; whereas in comorbidity, there is a reference to the index (or initial) disease $[1,2]$. Thus, MM is a more patient-centred construct, and comorbidity a disease-based construct; they characterise different perspectives of presenting co-existing diseases in a person [3].

The prevalence of MM currently affects around $13 \%$ of the population 18 years and older and $95 \%$ in patients aged 65 years and older [4]. MM is, at present, the rule and not the exception in most patients [5]. Publications on MM have been significantly increasing in the last few years [6,7], as the interest and importance of MM become an emerging priority [8]. This interest has even been accompanied by the creation of a specialised journal on MM (https://journals.sagepub.com/home/cob) - an outlet for publications of researchers involved in its study [6].

Bibliometric studies (i.e. number of citations and descriptive analysis) play an important role in the history of a specific scien- tific field when one is interested in studying the consolidated influence of an article, a researcher or an institution on the progress of scientific knowledge in a given moment or over time.

The relevance and popularity of studies regarding the mostcited articles aimed at scientific and medical communities alike are noticeably obvious [9]. Several reviews have previously been published on the most-cited articles regarding different medical disciplines, following different designs and searches in various databases $[10,11]$.

To date, only one bibliographic analysis has been published regarding both $\mathrm{MM}$ and comorbidity together [7]. This was done before the inclusion of $\mathrm{MM}$ as a MeSH term, and it aimed at describing global scientific research in comorbidity and $\mathrm{MM}$ until 8 November 2016. The study only analysed data from research articles and review articles, which could be considered as a limitation, as stated by the authors [7]. To the best of the authors' knowledge, no bibliometric analysis of $\mathrm{MM}$ has been done postinclusion of MM as a MeSH word.

\section{Objectives}

The objective of the current study was to identify the 100 most cited articles on multimorbidity and to analyse their features. For this purpose, the authors used data from Dimensions and Altmetric data within Dimensions (https://www.dimen- 
sions.ai/). Dimensions is a new inclusive scholarly search database that includes not only publications but also awarded grants, patents, clinical trials and Altmetric attention data, with an easy-to-use and flexible interface [12]. Dimensions also has good citation database coverage; by July 2019, it contained around $30 \%$ more publications than comparable databases: 102 million publications with over 1.2 billion citations openly accessible [13].

\section{Material and methods}

A cross-sectional analysis of the 100 most cited articles on multimorbidity in the scientific literature was done. No ethical approval was required for this type of study, as the analysed data was already available electronically in the databases.

Two reviewers performed a search in the new scholarly search database Dimensions from inception until 3 July 2019. In the search field, the keywords "multimorbidity" and "multi-morbidity", combined with the Boolean operator "OR", were inserted using the "title and abstract" search option. The results were ordered by number of citations, and the search was limited to articles only. No restrictions in languages or publication date were applied to the database search. A list of 4,302 publications was obtained, an, subsequently, two reviewers read the abstracts to see if, in fact, the articles referred to multimorbidity (all potential disagreements were resolved by consensus), thus reaching the top 100 most cited articles.

After the 100 most cited articles were selected, the following data was collected from each included article:

1) from Dimensions database: name of the journal in which the article was published, year of publication, first author's name, affiliation, country of origin, presence of specific financial support, Medical Subject Headings (MeSH) keywords, access type ("Closed" - no freely available copy; "All OA" (Open Access) - freely available copy; "Gold" - free copy available on the publisher page; "Green, Accepted \& Submitted" - free copy of accepted or submitted version in an OA repository), total citations (number of times that the article has been cited by other published publications in the Dimensions database, including articles, chapters, preprints, or monographs), recent citations (number of citations that were received within the last two years), Field Citation Ratio or FRC (relative citation performance of an article by comparing to articles of the same age in its sub- ject area. Values greater than 1.0 indicate a higher-than-average citation when defined by the subject field, publication year and age. The FCR is calculated for publications of at least two years of age and published in 2000 or later), Fields of Research (FoR) (classification of major fields and related sub-fields of research and emerging areas of study) and Altmetric Attention Score (weighted count of all the online attention Altmetric have found for individual research outpul; includes mentions in public policy documents and references in Wikipedia, mainstream news, social networks, blogs and others);

2) from SCImago (http://www.scimagojr.com/journalrank. $p h p)$ : the quartile of the category in which the journal was best positioned related to the article's publication year was recorded;

3) from Journal Citation Reports, Web of Science Group (http://jcr.clarivate.com/JCRLandingPageAction.action): 2018 impact factor of the journals;

4) type of article: each article was classified by the authors as original research, review article, position statement, or perspective/opinion/commentary.

The collected data was summarised as frequencies and percentages for categorical items and mean \pm standard deviation (SD) for numerical variable, using IBM SPSS Statistics for Windows, V.21.0 (IBM Corporation, Armonk, New York, USA). The graphs were produced using Excel Office 365 (Microsoft, Redmond, WA) and GraphPad Prism version 8.0.2 for Window, (GraphPad Software, San Diego, California USA). Like previously published work [7], the frequency of the MeSH keywords was visually represented by a "word cloud", generated free of charge by using wordclouds.com. It is a simple and clear tool where the most used MeSH keywords in the top 100 articles are those that stand out in the "word cloud".

\section{Results}

The number of citations for the top 100 most cited articles on MM ranged from 74 ( $100^{\text {th }}$ article) to 2,056 ( $1^{\text {st }}$ article) (mean $197.8 \pm 241.2$ citations). The total number of citations was 19,777 ( $40.5 \%$ were received within the last two years). All articles were written in English (Table 1). Most of the articles were classified as original research (65 articles - mean $174.6 \pm 255.6$ citations), followed by reviews ( 24 articles - mean $269.5 \pm 236.1$ citations), perspective/opinion/commentary (10 articles - mean $161.9 \pm 107.4$ citations, and 1 position statement (343 citations).

\begin{tabular}{|c|c|c|c|c|}
\hline Rank & Title & Journals & Reference $n \stackrel{0}{ }$ & $\begin{array}{l}\text { Times } \\
\text { cited }\end{array}$ \\
\hline 1 & $\begin{array}{l}\text { Epidemiology of multimorbidity and implications for } \\
\text { health care, research, and medical education: a cross- } \\
\text {-sectional study }\end{array}$ & The Lancet & 2012; 380: 37-43 & 2,056 \\
\hline 2 & $\begin{array}{l}\text { How to measure comorbidity a critical review of } \\
\text { available methods }\end{array}$ & Journal of Clinical Epidemiology & 2003; 56(3): 221-229 & 1007 \\
\hline 3 & $\begin{array}{l}\text { Aging with multimorbidity: a systematic review of the } \\
\text { literature }\end{array}$ & Ageing Research Reviews & 2011; 10(4): 430-439 & 814 \\
\hline 4 & $\begin{array}{l}\text { Defining comorbidity: implications for understanding } \\
\text { health and health services }\end{array}$ & The Annals of Family Medicine & 2009; 7(4): 357-363 & 607 \\
\hline 5 & $\begin{array}{l}\text { Multimorbidity in general practice: prevalence, inci- } \\
\text { dence, and determinants of co-occurring chronic and } \\
\text { recurrent diseases }\end{array}$ & Journal of Clinical Epidemiology & 1998; 51(5): 367-375 & 579 \\
\hline 6 & $\begin{array}{l}\text { Prevalence of multimorbidity among adults seen in } \\
\text { family practice }\end{array}$ & The Annals of Family Medicine & $2005 ; 3(3):$ 223-228 & 539 \\
\hline 7 & $\begin{array}{l}\text { Designing health care for the most common chronic } \\
\text { condition - multimorbidity }\end{array}$ & JAMA & 2012; 307(23): 2493-2494 & 390 \\
\hline 8 & $\begin{array}{l}\text { Multimorbidity and quality of life in primary care: } \\
\text { a systematic review }\end{array}$ & $\begin{array}{l}\text { Health and Quality of Life } \\
\text { Outcomes }\end{array}$ & 2004; 2(1): 51 & 382 \\
\hline 9 & $\begin{array}{l}\text { A systematic review of prevalence studies on multi- } \\
\text { morbidity: toward a more uniform methodology }\end{array}$ & The Annals of Family Medicine & 2012; 10(2): 142-151 & 368 \\
\hline
\end{tabular}




\begin{tabular}{|c|c|c|c|c|}
\hline Rank & Title & Journals & Reference $n \cong$ & $\begin{array}{l}\text { Times } \\
\text { cited }\end{array}$ \\
\hline 10 & $\begin{array}{l}\text { Epidemiology and impact of multimorbidity in pri- } \\
\text { mary care: a retrospective cohort study }\end{array}$ & $\begin{array}{l}\text { British Journal of General } \\
\text { Practice }\end{array}$ & 2011; 61(582): e12-e21 & 351 \\
\hline 11 & $\begin{array}{l}\text { Guiding principles for the care of older adults with } \\
\text { multimorbidity: an approach for clinicians }\end{array}$ & $\begin{array}{l}\text { Journal of the American Geriat- } \\
\text { rics Society }\end{array}$ & 2012; 60(10): e1-e25 & 343 \\
\hline 12 & $\begin{array}{l}\text { Morbidity and aging in HIV-infected persons: the } \\
\text { Swiss HIV Cohort Study }\end{array}$ & Clinical Infectious Diseases & 2011; 53(11): 1130-1139 & 339 \\
\hline 13 & Comorbidity or multimorbidity & $\begin{array}{l}\text { European Journal of General } \\
\text { Practice }\end{array}$ & 1996; 2(2): 65-70 & 333 \\
\hline 14 & Multimorbidity in older adults & Epidemiologic Reviews & 2013; 35(1): 75-83 & 300 \\
\hline 15 & $\begin{array}{l}\text { Managing patients with multimorbidity: systematic } \\
\text { review of interventions in primary care and commu- } \\
\text { nity settings }\end{array}$ & The $B M J$ & 2012; 345(sep03 1): e5205 & 298 \\
\hline 16 & Multimorbidity's many challenges & The BMJ & $\begin{array}{l}2007 ; 334(7602): \\
1016-1017\end{array}$ & 292 \\
\hline 17 & $\begin{array}{l}\text { Relationship between multimorbidity and health- } \\
\text {-related quality of life of patients in primary care }\end{array}$ & Quality of Life Research & 2006; 15(1): 83-91 & 284 \\
\hline 18 & $\begin{array}{l}\text { Measures of multimorbidity and morbidity burden } \\
\text { for use in primary care and community settings: a sys- } \\
\text { tematic review and guide }\end{array}$ & The Annals of Family Medicine & 2012; 10(2): 134-141 & 260 \\
\hline 19 & $\begin{array}{l}\text { The prevalence of multimorbidity in primary care and } \\
\text { its effect on health care utilization and cost }\end{array}$ & Family Practice & 2011; 28(5): 516-523 & 250 \\
\hline 20 & $\begin{array}{l}\text { The measurement of multiple chronic diseases } \\
\text { - a systematic review on existing multimorbidity } \\
\text { indices }\end{array}$ & $\begin{array}{l}\text { The Journals of Gerontology } \\
\text { Series A }\end{array}$ & 2011; 66A(3): 301-311 & 248 \\
\hline 21 & $\begin{array}{l}\text { Future of multimorbidity research: how should un- } \\
\text { derstanding of multimorbidity inform health system } \\
\text { design? }\end{array}$ & Public Health Reviews & 2010; 32(2): 451-474 & 248 \\
\hline 22 & $\begin{array}{l}\text { Adapting clinical guidelines to take account of multi- } \\
\text { morbidity }\end{array}$ & The BMJ & 2012; 345(oct04 1): e6341 & 235 \\
\hline 23 & $\begin{array}{l}\text { Multimorbidity in primary care: prevalence and trend } \\
\text { over the last } 20 \text { years }\end{array}$ & $\begin{array}{l}\text { European Journal of General } \\
\text { Practice }\end{array}$ & 2008; 14(sup 1): 28-32 & 218 \\
\hline 24 & $\begin{array}{l}\text { Prevalence and patterns of multimorbidity in Aus- } \\
\text { tralia }\end{array}$ & The Medical Journal of Australia & 2008; 189(2): 72-77 & 218 \\
\hline 25 & $\begin{array}{l}\text { Prevalence of chronic diseases and multimorbidity } \\
\text { among the elderly population in Sweden }\end{array}$ & $\begin{array}{l}\text { American Journal of Public } \\
\text { Health }\end{array}$ & 2008; 98(7): 1198-1200 & 217 \\
\hline 26 & $\begin{array}{l}\text { Prevalence, determinants and patterns of multi- } \\
\text { morbidity in primary care: a systematic review of } \\
\text { observational studies }\end{array}$ & PLOS ONE & 2014; 9(7): e102149 & 217 \\
\hline 27 & $\begin{array}{l}\text { Patterns of chronic multimorbidity in the elderly } \\
\text { population }\end{array}$ & $\begin{array}{l}\text { Journal of the American Geriat- } \\
\text { rics Society }\end{array}$ & 2009; 57(2): 225-230 & 212 \\
\hline 28 & $\begin{array}{l}\text { Guidelines for people not for diseases: the challenges } \\
\text { of applying UK clinical guidelines to people with } \\
\text { multimorbidity }\end{array}$ & Age and Ageing & 2013; 42(1): 62-69 & 210 \\
\hline 29 & $\begin{array}{l}\text { Processes of care desired by elderly patients with } \\
\text { multimorbidities }\end{array}$ & Family Practice & 2008; 25(4): 287-293 & 180 \\
\hline 30 & $\begin{array}{l}\text { Association of cardiometabolic multimorbidity with } \\
\text { mortality }\end{array}$ & $J A M A$ & 2015; 314(1): 52-60 & 175 \\
\hline 31 & $\begin{array}{l}\text { Multimorbidity patterns in the elderly: a new ap- } \\
\text { proach of disease clustering identifies complex inter- } \\
\text { relations between chronic conditions }\end{array}$ & PLOS ONE & 2010; 5(12): e15941 & 170 \\
\hline 32 & $\begin{array}{l}\text { Which chronic diseases and disease combinations are } \\
\text { specific to multimorbidity in the elderly? Results of } \\
\text { a claims data based cross-sectional study in Germany }\end{array}$ & BMC Public Health & 2011; 11(1): 101 & 164 \\
\hline 33 & $\begin{array}{l}\text { The impact of chronic multimorbidity and disability } \\
\text { on functional decline and survival in elderly persons. } \\
\text { A community-based, longitudinal study }\end{array}$ & Journal of Internal Medicine & $2009 ; 265(2): 288-295$ & 163 \\
\hline 34 & $\begin{array}{l}\text { The association between chronic illness, multimor- } \\
\text { bidity and depressive symptoms in an Australian } \\
\text { primary care cohort }\end{array}$ & $\begin{array}{l}\text { Social Psychiatry and Psychiatric } \\
\text { Epidemiology }\end{array}$ & 2012; 47(2): 175-184 & 161 \\
\hline 35 & $\begin{array}{l}\text { Managing patients with multimorbidity in primary } \\
\text { care }\end{array}$ & The BMJ & 2015; 350(jan20 2): h176 & 158 \\
\hline
\end{tabular}




\begin{tabular}{|c|c|c|c|c|}
\hline Rank & | Title & Journals & Reference $n \cong$ & $\begin{array}{l}\text { Times } \\
\text { cited }\end{array}$ \\
\hline 36 & Multimorbidity patterns: a systematic review & Journal of Clinical Epidemiology & $2014 ; 67(3): 254-266$ & 158 \\
\hline 37 & $\begin{array}{l}\text { Prevalence of morbidity and multimorbidity in } \\
\text { elderly male populations and their impact on 10-year } \\
\text { all-cause mortality. The FINE study (Finland, Italy, } \\
\text { Netherlands, elderly) }\end{array}$ & Journal of Clinical Epidemiology & $2001 ; 54(7): 680-686$ & 158 \\
\hline 38 & $\begin{array}{l}\text { Prevalence estimates of multimorbidity: a compara- } \\
\text { tive study of two sources }\end{array}$ & BMC Health Services Research & 2010; 10(1): 111 & 156 \\
\hline 39 & $\begin{array}{l}\text { Barriers to self-management and quality-of-life out- } \\
\text { comes in seniors with multimorbidities }\end{array}$ & The Annals of Family Medicine & 2007; 5(5): 395-402 & 156 \\
\hline 40 & $\begin{array}{l}\text { Interventions for improving outcomes in patients } \\
\text { with multimorbidity in primary care and community } \\
\text { settings }\end{array}$ & $\begin{array}{l}\text { Cochrane Database of System- } \\
\text { atic Reviews }\end{array}$ & 2016; 3(3): cd006560 & 151 \\
\hline 41 & $\begin{array}{l}\text { Effects of physical exercise therapy on mobility, physi- } \\
\text { cal functioning, physical activity and quality of life } \\
\text { in community-dwelling older adults with impaired } \\
\text { mobility, physical disability and/or multi-morbidity: } \\
\text { a meta-analysis }\end{array}$ & Ageing Research Reviews & 2012; 11(1): 136-149 & 146 \\
\hline 42 & Guided care for multimorbid older adults & The Gerontologist & 2007; 47(5): 697-704 & 138 \\
\hline 43 & $\begin{array}{l}\text { The influence of age, gender and socio-economic } \\
\text { status on multimorbidity patterns in primary care. } \\
\text { First results from the multicare cohort study }\end{array}$ & BMC Health Services Research & $2012 ; 12(1): 89$ & 135 \\
\hline 44 & $\begin{array}{l}\text { Multimorbidity in primary care: developing the } \\
\text { research agenda }\end{array}$ & Family Practice & 2009; 26(2): 79-80 & 134 \\
\hline 45 & $\begin{array}{l}\text { Multimorbidity is common to family practice: is it } \\
\text { commonly researched? }\end{array}$ & Canadian Family Physician & $2005 ; 51: 244-245$ & 131 \\
\hline 46 & $\begin{array}{l}\text { Psychological distress and multimorbidity in primary } \\
\text { care }\end{array}$ & The Annals of Family Medicine & $2006 ; 4(5): 417-422$ & 131 \\
\hline 47 & $\begin{array}{l}\text { Multimorbidity: redesigning health care for people } \\
\text { who use it }\end{array}$ & The Lancet & 2012; 380(9836): 7-9 & 127 \\
\hline 48 & Multimorbidity and quality of life: a closer look & $\begin{array}{l}\text { Health and Quality of Life } \\
\text { Outcomes }\end{array}$ & 2007; 5(1): 52 & 122 \\
\hline 49 & $\begin{array}{l}\text { Multimorbidity - not just an older person's issue. } \\
\text { Results from an Australian biomedical study }\end{array}$ & BMC Public Health & 2010; 10(1): 718 & 121 \\
\hline 50 & $\begin{array}{l}\text { The increasing burden and complexity of multimor- } \\
\text { bidity }\end{array}$ & BMC Public Health & 2015; 15(1): 415 & 115 \\
\hline 51 & $\begin{array}{l}\text { GPs' perspectives on the management of patients } \\
\text { with multimorbidity: systematic review and synthesis } \\
\text { of qualitative research }\end{array}$ & BMJ Open & 2013; 3(9): e003610 & 115 \\
\hline 52 & $\begin{array}{l}\text { Problems in determining occurrence rates of multi- } \\
\text { morbidity }\end{array}$ & Journal of Clinical Epidemiology & 2001; 54(7): 675-679 & 115 \\
\hline 53 & $\begin{array}{l}\text { Multimorbidity and comorbidity in the Dutch popula- } \\
\text { tion - data from general practices }\end{array}$ & BMC Public Health & 2012; 12(1): 715 & 114 \\
\hline 54 & $\begin{array}{l}\text { Deprescribing medication in very elderly patients } \\
\text { with multimorbidity: the view of Dutch GPs. A quali- } \\
\text { tative study }\end{array}$ & BMC Family Practice & 2012; 13(1): 56 & 114 \\
\hline 55 & $\begin{array}{l}\text { Cumulative Illness Rating Scale was a reliable and } \\
\text { valid index in a family practice context }\end{array}$ & Journal of Clinical Epidemiology & $2005 ; 58(6): 603-608$ & 113 \\
\hline 56 & $\begin{array}{l}\text { Comparative assessment of three different indices of } \\
\text { multimorbidity for studies on health-related quality } \\
\text { of life }\end{array}$ & $\begin{array}{l}\text { Health and Quality of Life } \\
\text { Outcomes }\end{array}$ & $2005 ; 3(1): 74$ & 112 \\
\hline 57 & $\begin{array}{l}\text { Integrated primary care for patients with mental } \\
\text { and physical multimorbidity: cluster randomised } \\
\text { controlled trial of collaborative care for patients with } \\
\text { depression comorbid with diabetes or cardiovascular } \\
\text { disease }\end{array}$ & The BMJ & 2015; 350(feb16 3): h638 & 111 \\
\hline 58 & $\begin{array}{l}\text { Patterns of multimorbidity in the aged population. } \\
\text { Results from the KORA-Age Study }\end{array}$ & PLOS ONE & 2012; 7(1): e30556 & 109 \\
\hline 59 & $\begin{array}{l}\text { The effect of physical multimorbidity, mental health } \\
\text { conditions and socioeconomic deprivation on } \\
\text { unplanned admissions to hospital: a retrospective } \\
\text { cohort study }\end{array}$ & $\begin{array}{l}\text { Canadian Medical Association } \\
\text { Journal }\end{array}$ & 2013; 185(5): e221-e228 & 109 \\
\hline
\end{tabular}




\begin{tabular}{|c|c|c|c|c|}
\hline Rank & Title & Journals & 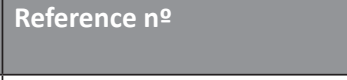 & $\begin{array}{l}\text { Times } \\
\text { cited }\end{array}$ \\
\hline 60 & $\begin{array}{l}\text { Shifting priorities in multimorbidity: a longitudinal } \\
\text { qualitative study of patient's prioritization of multiple } \\
\text { conditions }\end{array}$ & Chronic Illness & 2011; 7(2): 147-161 & 108 \\
\hline 61 & $\begin{array}{l}\text { Setting and registry characteristics affect the preva- } \\
\text { lence and nature of multimorbidity in the elderly }\end{array}$ & Journal of Clinical Epidemiology & 2008; 61(11): 1104-1112 & 107 \\
\hline 62 & $\begin{array}{l}\text { Suicide risk in primary care patients with major physi- } \\
\text { cal diseases: a case-control study }\end{array}$ & JAMA Psychiatry & $2012 ; 69(3): 256-264$ & 106 \\
\hline 63 & $\begin{array}{l}\text { Multimorbidity is associated with better quality of } \\
\text { care among vulnerable elders }\end{array}$ & Medical Care & 2007; 45(6): 480-488 & 105 \\
\hline 64 & $\begin{array}{l}\text { Unpacking the burden: understanding the relation- } \\
\text { ships between chronic pain and comorbidity in the } \\
\text { general population }\end{array}$ & Pain & 2012; 153(2): 293-304 & 105 \\
\hline 65 & $\begin{array}{l}\text { What matters to older people with assisted living } \\
\text { needs? A phenomenological analysis of the use and } \\
\text { non-use of telehealth and telecare }\end{array}$ & Social Science \& Medicine & 2013; 93: 86-94 & 105 \\
\hline 66 & $\begin{array}{l}\text { Clinical multimorbidity and physical function in older } \\
\text { adults: a record and health status linkage study in } \\
\text { general practice }\end{array}$ & Family Practice & 2007; 24(5): 412-419 & 104 \\
\hline 67 & $\begin{array}{l}\text { Multimorbidity, health care utilization and costs in an } \\
\text { elderly community-dwelling population: a claims data } \\
\text { based observational study }\end{array}$ & BMC Health Services Research & 2015; 15(1): 23 & 104 \\
\hline 68 & $\begin{array}{l}\text { Multimorbidity patterns in primary care: interactions } \\
\text { among chronic diseases using factor analysis }\end{array}$ & PLOS ONE & 2012; 7(2): e32190 & 103 \\
\hline 69 & $\begin{array}{l}\text { Multimorbidity and survival in older persons with } \\
\text { colorectal cancer }\end{array}$ & $\begin{array}{l}\text { Journal of the American Geriat- } \\
\text { rics Society }\end{array}$ & 2006; 54(12): 1898-1904 & 102 \\
\hline 70 & $\begin{array}{l}\text { Hospital admissions among people } 65+\text { related to } \\
\text { multimorbidity, municipal and outpatient care }\end{array}$ & $\begin{array}{l}\text { Archives of Gerontology and } \\
\text { Geriatrics }\end{array}$ & 2008; 46(1): 41-55 & 101 \\
\hline 71 & $\begin{array}{l}\text { Collaborative care needs and preferences of primary } \\
\text { care patients with multimorbidity }\end{array}$ & Health Expectations & 2005; 8(1): 54-63 & 101 \\
\hline 72 & $\begin{array}{l}\text { Drug-disease and drug-drug interactions: systematic } \\
\text { examination of recommendations in } 12 \text { UK national } \\
\text { clinical guidelines }\end{array}$ & The BMJ & 2015; 350(mar11 2): h949 & 101 \\
\hline 73 & $\begin{array}{l}\text { Multimorbidity prevalence and patterns across socio- } \\
\text { economic determinants: a cross-sectional survey }\end{array}$ & BMC Public Health & 2012; 12(1): 201 & 100 \\
\hline 74 & $\begin{array}{l}\text { Global multimorbidity patterns: a cross-sectional, } \\
\text { population-based, multi-country study }\end{array}$ & $\begin{array}{l}\text { The Journals of Gerontology } \\
\text { Series A }\end{array}$ & $2016 ; 71(2): 205-214$ & 99 \\
\hline 75 & $\begin{array}{l}\text { Beyond diagnosis: rising to the multimorbidity chal- } \\
\text { lenge }\end{array}$ & The BMJ & 2012; 344(jun13 2): e3526 & 98 \\
\hline 76 & $\begin{array}{l}\text { Multimorbidity, service organization and clinical deci- } \\
\text { sion making in primary care: a qualitative study }\end{array}$ & Family Practice & 2011; 28(5): 579-587 & 96 \\
\hline 77 & $\begin{array}{l}\text { The Ariadne principles: how to handle multimorbidity } \\
\text { in primary care consultations }\end{array}$ & BMC Medicine & 2014; 12(1): 223 & 95 \\
\hline 78 & $\begin{array}{l}\text { Co- and multimorbidity patterns in primary care } \\
\text { based on episodes of care: results from the German } \\
\text { CONTENT project }\end{array}$ & BMC Health Services Research & $2008 ; 8(1): 14$ & 93 \\
\hline 79 & $\begin{array}{l}\text { Disability, more than multimorbidity, was predictive } \\
\text { of mortality among older persons aged } 80 \text { years and } \\
\text { older }\end{array}$ & Journal of Clinical Epidemiology & 2010; 63(7): 752-759 & 90 \\
\hline 80 & Better management of patients with multimorbidity & The BMJ & 2013; 346(may02 1): f2510 & 90 \\
\hline 81 & $\begin{array}{l}\text { The European general practice research network } \\
\text { presents a comprehensive definition of multimorbid- } \\
\text { ity in family medicine and long-term care, following } \\
\text { a systematic review of relevant literature }\end{array}$ & $\begin{array}{l}\text { Journal of the American Medical } \\
\text { Directors Association }\end{array}$ & 2013; 14(5): 319-325 & 89 \\
\hline 82 & $\begin{array}{l}\text { Seniors' self-reported multimorbidity captured bio- } \\
\text { psychosocial factors not incorporated into two other } \\
\text { data-based morbidity measures }\end{array}$ & Journal of Clinical Epidemiology & 2009; 62(5): 550-557.e1 & 88 \\
\hline 83 & $\begin{array}{l}\text { Aging and multimorbidity: new tasks, priorities, and } \\
\text { frontiers for integrated gerontological and clinical } \\
\text { research }\end{array}$ & $\begin{array}{l}\text { Journal of the American Medical } \\
\text { Directors Association }\end{array}$ & 2015; 16(8): 640-647 & 86 \\
\hline 84 & $\begin{array}{l}\text { Multimorbidity: prevalence, effect on quality of life } \\
\text { and daily functioning, and variation of this effect } \\
\text { when one condition is a rheumatic disease }\end{array}$ & $\begin{array}{l}\text { Seminars in Arthritis and Rheu- } \\
\text { matism }\end{array}$ & 2009; 38(4): 312-319 & 83 \\
\hline
\end{tabular}




\begin{tabular}{|c|c|c|c|c|}
\hline Rank & Title & Journals & Reference $n \cong$ & $\begin{array}{l}\text { Times } \\
\text { cited }\end{array}$ \\
\hline 85 & $\begin{array}{l}\text { Multimorbidity in primary care: a systematic review } \\
\text { of prospective cohort studies }\end{array}$ & $\begin{array}{l}\text { British Journal of General } \\
\text { Practice }\end{array}$ & 2012; 62(597): e297-e307 & 83 \\
\hline 86 & $\begin{array}{l}\text { Prevalence of multimorbidity in a geographically } \\
\text { defined American population patterns by age, sex, } \\
\text { and race/ethnicity }\end{array}$ & Mayo Clinic Proceedings & 2014; 89(10): 1336-1349 & 82 \\
\hline 87 & $\begin{array}{l}\text { Managing patients with mental and physical multi- } \\
\text { morbidity }\end{array}$ & The BMJ & 2012; 345(sep03 1): e5559 & 80 \\
\hline 88 & $\begin{array}{l}\text { The impact of multimorbidity on adult physical and } \\
\text { mental health in low- and middle-income countries: } \\
\text { what does the study on global ageing and adult } \\
\text { health (SAGE) reveal? }\end{array}$ & BMC Medicine & 2015; 13(1): 178 & 79 \\
\hline 89 & $\begin{array}{l}\text { Comparing measures of multimorbidity to predict } \\
\text { outcomes in primary care: a cross sectional study }\end{array}$ & Family Practice & 2013; 30(2): 172-178 & 79 \\
\hline 90 & $\begin{array}{l}\text { Multiple diseases and polypharmacy in the elderly: } \\
\text { challenges for the internist of the third millennium }\end{array}$ & Journal of Comorbidity & 2011; 1(1): 28-44 & 79 \\
\hline 91 & $\begin{array}{l}\text { Multimorbidity - older adults need health care that } \\
\text { can count past one }\end{array}$ & The Lancet & 2015; 385(9968): 587-589 & 78 \\
\hline 92 & $\begin{array}{l}\text { Examining different measures of multimorbidity, } \\
\text { using a large prospective cross-sectional study in } \\
\text { Australian general practice }\end{array}$ & BMJ Open & 2014; 4(7): e004694 & 77 \\
\hline 93 & $\begin{array}{l}\text { Prevalence of polypharmacy in a Scottish primary } \\
\text { care population }\end{array}$ & $\begin{array}{l}\text { European Journal of Clinical } \\
\text { Pharmacology }\end{array}$ & 2014; 70(5): 575-581 & 77 \\
\hline 94 & Multimorbidity patterns in HIV-infected patients & $\begin{array}{l}\text { JAIDS Journal of Acquired Im- } \\
\text { mune Deficiency Syndromes }\end{array}$ & 2012; 61(5): 600-605 & 76 \\
\hline 95 & $\begin{array}{l}\text { A framework for crafting clinical practice guidelines } \\
\text { that are relevant to the care and management of } \\
\text { people with multimorbidity }\end{array}$ & $\begin{array}{l}\text { Journal of General Internal } \\
\text { Medicine }\end{array}$ & 2014; 29(4): 670-679 & 76 \\
\hline 96 & $\begin{array}{l}\text { Symptom burden in community-dwelling older } \\
\text { people with multimorbidity: a cross-sectional study }\end{array}$ & BMC Geriatrics & 2015; 15(1): 1 & 76 \\
\hline 97 & $\begin{array}{l}\text { The prevalence of chronic diseases and multimorbid- } \\
\text { ity in primary care practice: a PPRNet report }\end{array}$ & $\begin{array}{l}\text { The Journal of the American } \\
\text { Board of Family Medicine }\end{array}$ & 2013; 26(5): 518-524 & 75 \\
\hline 98 & $\begin{array}{l}\text { Multimorbidity of chronic diseases and health care } \\
\text { utilization in general practice }\end{array}$ & BMC Family Practice & 2014; 15(1): 61 & 75 \\
\hline 99 & $\begin{array}{l}\text { Multimorbidity and health-related quality of life in } \\
\text { the older population: results from the German KORA- } \\
\text { Age study }\end{array}$ & $\begin{array}{l}\text { Health and Quality of Life } \\
\text { Outcomes }\end{array}$ & 2011; 9(1): 53 & 75 \\
\hline 100 & $\begin{array}{l}\text { Patterns of comorbidity and multimorbidity in the } \\
\text { oldest old: the Octabaix study }\end{array}$ & $\begin{array}{l}\text { European Journal of Internal } \\
\text { Medicine }\end{array}$ & $2013 ; 24(1): 40-44$ & 74 \\
\hline
\end{tabular}

The top 3 most cited articles were: 1) a cross-sectional study published in 2012 by Barnett et al. [14] in the journal The Lancet, describing the epidemiology of multimorbidity in Scottish patients (2,056 citations); 2 ) a systematic review of MM measures published by de Groot et al. [15] in 2003 in the Journal of Clinical Epidemiology (1,007 citations); and 3) a systematic review about multimorbidity in older persons published in 2011 by Marengoni et al. [16] in the journal Ageing Research Reviews (814 citations). The highest number of recent citations (i.e. received within the last two years) was found for the study by Barnet et al. [14] with 1,064 total citations (51.8\%), followed by the study by Marengoni et al. [16] with 417 total citations (51.2\%).

Compared to other publications in the same field, the 100 most cited articles on MM received at least 7.9 times more citations than average. The Field Citation Ratio (FCR) was the uppermost for the study by Barnet et al. [14]; it was extremely highly cited, with approximately 282 times more citations than the average for the Public Health and Health Services field of research. The study by Marengoni et al. [16] received approximately 102 times more citations than the average for the same field of research, and the study by de Groot et al. [15] received 82 times more citations than the average for the Clinical Sciences field of research.
Using Altmetric, the online activity surrounding the top 100 most cited articles had a score between nil and 406. A top 5 High Attention Score compared to outputs of the same age and source was found for the studies of Barnet et al. [14] (99 percentile), Dumbreck et al. [17] (95 $5^{\text {th }}$ percentile), Wallace et al. [18] (92 ${ }^{\text {nd }}$ percentile), Emerging Risk Factors Collaboration [19] ( $86^{\text {th }}$ percentile) and Coventry et al. [20] ( $90^{\text {th }}$ percentile). These articles were published in The Lancet, BMJ and JAMA. Figure 1 shows that the first 15 articles in the top 100 list received more media mentions and have more readers than the bottom 15 articles (i.e. rank 86 to 100).

The 100 most cited articles on MM were published between 1996 and 2016 (Figure 2). The years with the greatest number of published articles were $2012(n=22), 2011(n=10), 2013(n=$ $10)$ and $2015(n=10)$. More than half of the 100 most cited articles on MM were published after 2010. The oldest article was the $13^{\text {th }}$ most cited (333 citations) and was published by van den Akker et al. [2] in 1996. In this review article, the authors suggested a distinction between MM and comorbidity. The most recent article was a Cochrane Review concerning interventions for improving outcomes in patients with multimorbidity [21] with 99 citations $-74^{\text {th }}$ position.

The number of authors that wrote the articles in the top 100 varied between a single author in 3 articles [22-24] and more than 


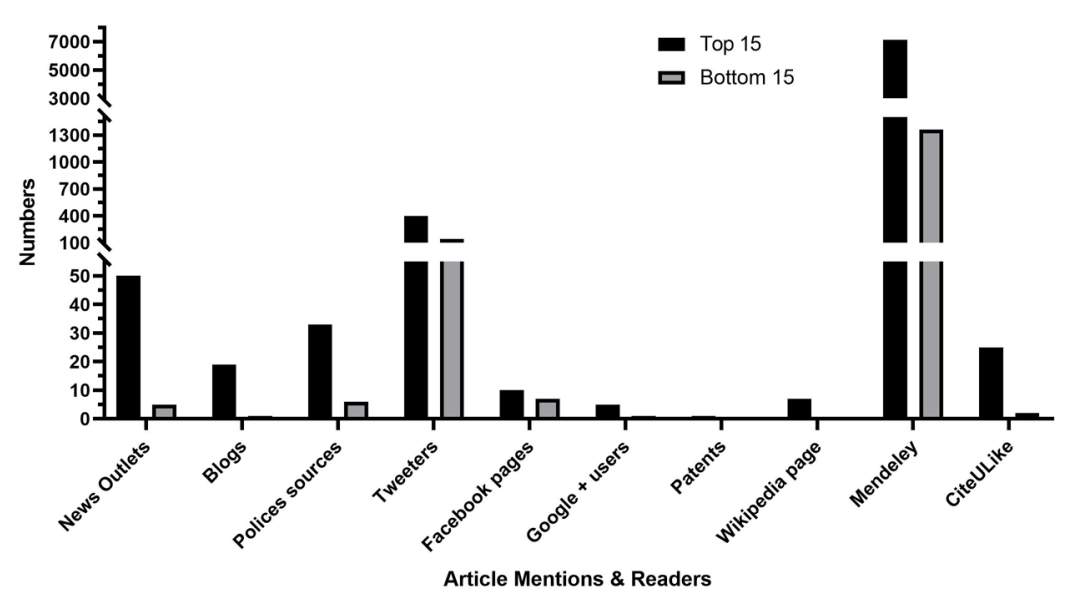

Figure 1. Mentions and readers of the Top 15 and Bottom 15 articles in the Top 100 list

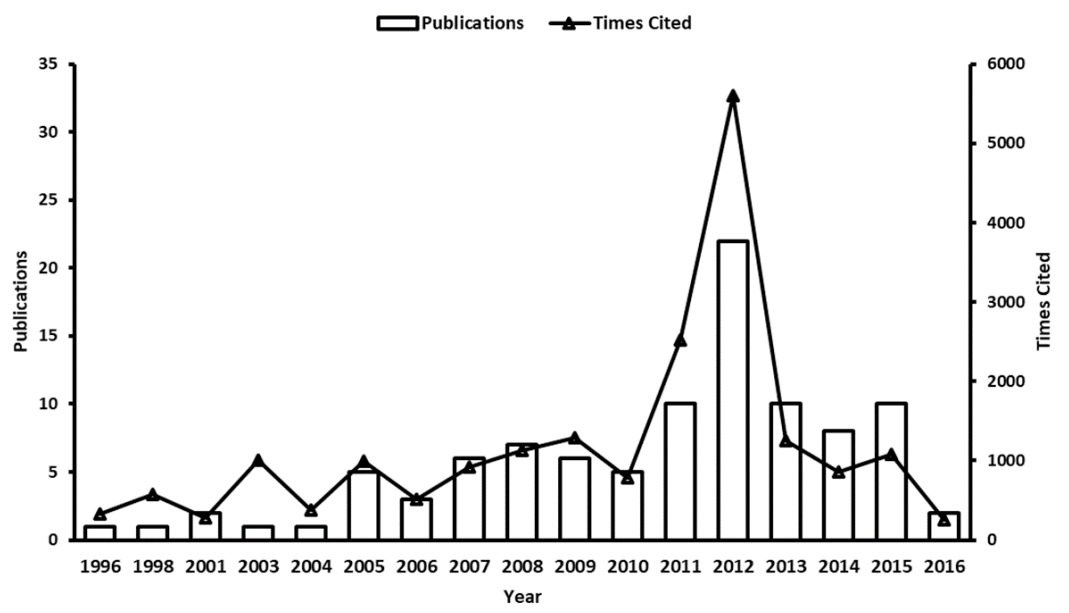

Figure 2. Number of articles published each year and total of citations per year

80 authors in an Emerging Risk Factors Collaboration study published in 2015 in JAMA [19] (mean number of authors $7.1 \pm 9.0$ ). As first authors, the most proficient researchers (with 3 or more articles in the top 100) were: Martin Fortin (10 articles) [5, 25-33], Alessandra Marengoni (4 articles) [16, 34-36], Elizabeth Bayliss (3 articles) [37-39] and Marjan van den Akker (3 articles) [2, 40, 41].

The first authors of the 100 most cited articles on MM were associated with 61 primary institutions; the 5 most frequent were: Université de Sherbrooke (11 articles), University of Manchester (5 articles), University of Dundee (4 articles), University of Cambridge ( 4 articles) and University of Bristol (4 articles).
Funding was stated in $53 \%$ of the articles.

Thirteen different countries were present in the top 100 list. The greatest number of published articles were from the United Kingdom (24 articles), the United States (16 articles), Canada (13 articles), the Netherlands (11 articles) and Germany ( 8 articles), establishing a top 5 list that represented $72 \%$ of the total articles. Other countries included Sweden, Spain, Ireland, Australia, Switzerland, Italy, New Zealand and India.

The 100 most cited articles on MM were published in 48 journals, but only 10 of these journals represented $53 \%$ of the articles published and $61.1 \%$ of the total of citations (Table 2 ).

\begin{tabular}{|l|l|l|l|l|l|l|}
\hline Table 2. Journals with the highest number articles in the top $\mathbf{1 0 0}$ list (3 or more articles) \\
\hline Journal & $\begin{array}{l}\text { No. of } \\
\text { articles }\end{array}$ & $\begin{array}{l}\text { No. of closed } \\
\text { access articles }\end{array}$ & $\begin{array}{l}\text { No. of open } \\
\text { access articles }\end{array}$ & $\begin{array}{l}\text { SClmago } \\
\text { Journal Rank } \\
\text { Quartile }\end{array}$ & $\begin{array}{l}2018 \text { Journal } \\
\text { Impact Factor }\end{array}$ & $\begin{array}{l}\text { Total of } \\
\text { times cited }\end{array}$ \\
\hline The BMJ & 9 & 2 & 7 & Q1 & 27.604 & 1,463 \\
\hline Journal of Clinical Epidemiology & 9 & 8 & 1 & Q1 & 4.650 & 2,415 \\
\hline Family Practice & 6 & - & 6 & Q1 & 1.986 & 843 \\
\hline The Annals of Family Medicine & 6 & - & 6 & Q1 & 4.185 & 2,061 \\
\hline BMC Public Health & 5 & - & 5 & Q1 & 2.567 & 614 \\
\hline PLoS ONE & 4 & - & 4 & Q1 & 2.776 & 599 \\
\hline Health and Quality of Life Outcomes & 4 & - & 4 & Q1/Q2 & 2.318 & 691 \\
\hline BMC Health Services Research & 4 & - & 4 & Q1 & 1.932 & 488 \\
\hline The Lancet & 3 & 3 & - & Q1 & 59.102 & 2,261 \\
\hline Journal of the American Geriatrics Society & 3 & 2 & 1 & Q1 & 4.113 & 657 \\
\hline Total & 53 & 15 & 38 & - & - & 12,092 \\
\hline
\end{tabular}




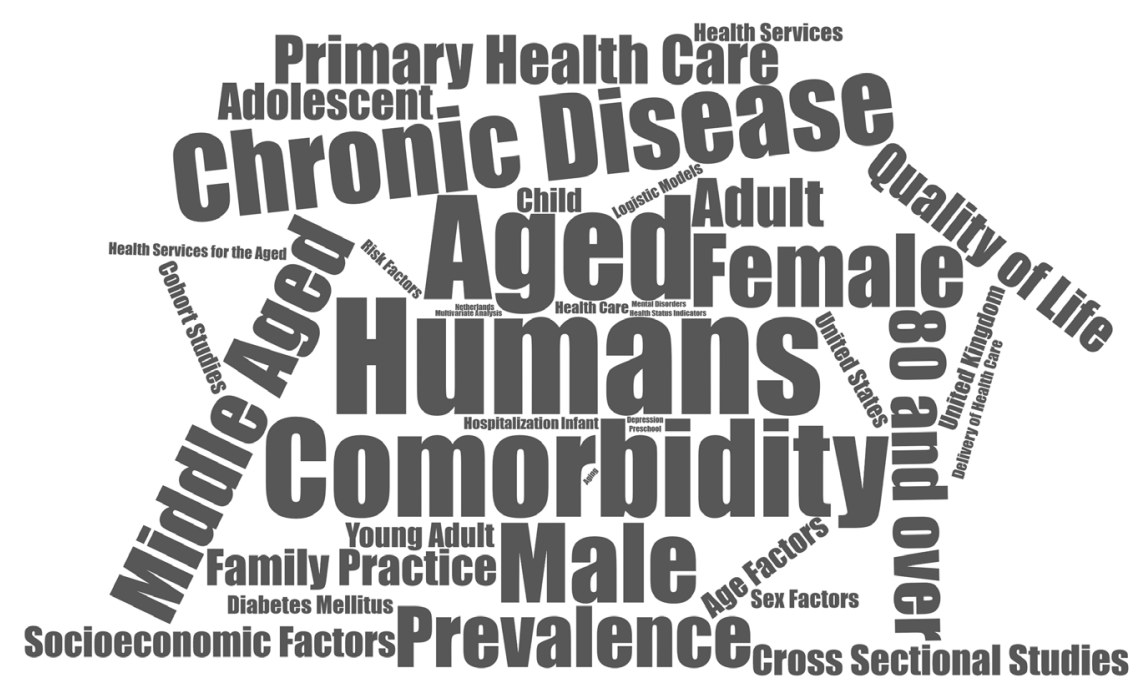

Figure 3. Word cloud for the most frequently used keywords (mentioned at least 5 times) in classic articles (100 or more citations)

Regarding access to the top 100 articles, the majority (70\%) were published in Open Access (OA) format: 56 articles in OA Gold - mean $164.6 \pm 1104$ citations; 9 in OA Green (accepted \& submitted) - mean $179.4 \pm 122.2$ citations; and 5 in OA Green (published) - mean $209.0 \pm 118.1$ citations. The remaining articles were published in Closed Access (mean $263.4 \pm 403.4$ citations).

According to the SCImago Journal Rank, the best quartile related to the publication year was Q1 (quarter of the journals with the highest values) for 93 articles, Q2 (the second highest values) for 3 articles, and 4 journals were not indexed.

From the 100 most cited articles, 97 were indexed with an Impact Factor (IF) in the Web of Science Journal Citation Reports. The journal with the highest IF was The Lancet (59.102), and the lowest IF was from the European Journal of General Practice $(1,617)$.

The two most common research categories were Public Health and Health Services ( 76 articles) and Clinical Sciences ( 7 articles). Other categories included Statistics, Cardiorespiratory Medicine and Haematology, Neurosciences, Nursing, Sociology and other studies in Human Society.

Of the 100 most cited articles on MM, 73 papers can be identified as "classic" (100 or more citations [42]). The most frequently used MeSH keywords (mentioned at least 5 times) extracted from the classic articles are depicted in Figure 3.

\section{Discussion}

In the current cross-sectional study, the authors analysed the 100 most cited articles on multimorbidity present in the scientific database Dimensions, an inter-linked research information system provided by Digital Science (https://www.dimensions.ai), from inception until 3 July 2019. This is the first bibliometric analysis of MM done after its inclusion as a MeSH word in 2018 by the National Library of Medicine. This study uses not only classic bibliometric indicators but also some Altmetric data, which may provide a more complete picture of the influence of multimorbidity research as mentioned in literature $[9,43]$.

The most obvious finding to emerge from this analysis is that more than half of the articles in the top 100 were published after 2010 , revealing the recent interest in this topic $-40.5 \%$ of the total number of citations was received within the last two years. This finding is consistent with a recent review by other authors, in which approximately two-thirds of the papers on comorbidity and multimorbidity were published since 2010 [7]. Remarkably, it was only in 1996 that multimorbidity was defined as the co-occurrence of two or more chronic diseases within a patient without an index disease [2]. The scientific importance of MM research is also noticeable from the current analysis, as the top 100 articles received at least 7.9 times more citations than the average compared to other publications in the same field, especially in the Public Health and Health Services category.

Although thirteen different countries were present in the top 100 list, English was the only language of the 100 widelycited articles on multimorbidity. This result reflects the known impression that English is the international language of scientific communication [44, 45], and reporting multimorbidity findings is no exception. Actually, English is the language of $80 \%$ of Scopus-indexed journals and is noticeably rising in publications by several non-native English speaking countries [45]. English is also the most common Internet language, and with the current increase in medical journals in Open Access electronic format, the publication of articles in English favours circulation on the Internet $-70 \%$ of the top 100 articles were published in Open Access format.

In contrast to earlier findings, in which scientific productivity was dominated by the United States [7], almost three-fourths of the 100 most cited articles on multimorbidity were from Europe, the United States and Canada. This is unsurprising given the increase in international competition for recognition and reward of the research done by non-Anglophone researchers $[46,47]$.

As expected, this study confirms that in multimorbidity, as in other areas, review articles are more often cited than original articles [48-50], even though there was a higher number of original articles in the top 100. A possible explanation for this might be that since multimorbidity is a recent research field and that review articles are comprehensive and summarise existing literature, a researcher who starts working on multimorbidity will go through the existing review articles, adding to the articles' citation count for any subsequent original article published by that researcher. One unanticipated finding was the presence of a significant number of perspective/opinion/commentary articles in the top 100 most cited articles on MM. These are usually excluded in citation indicators, but in the case of MM, they may be a venue to easily express pioneering ideas [50].

The 100 most cited articles on MM were published in international journals, and almost all were in the first quartile for their category. The most cited articles were concentrated in a few journals, which corroborates earlier similar findings in fields with high citation density [51]. It seems possible that authors follow the notion that the impact factor of the publishing journal is a predictor of future citations [52], and so they choose to publish in journals in the first quartile. 
Nonetheless, some journals with less than three papers in the 100 most cited list had a high impact factor according to 2018 Journal Citation Reports.

This research found that in classic multimorbidity articles, not only "aged" ( $n=70 ; 96 \%)$ and "comorbidity" ( $n=61 ; 84 \%)$, but also "80 and over" $(n=24)$, "middle aged" $(n=28)$, "chronic disease" ( $n=48)$, "prevalence" $(n=26)$, "Primary Health Care" $(n=23)$, "Quality of Life" $(n=13)$ and "Family Practice" ( $n=$ 12 ) were very common. This is consistent with previous findings in which articles on comorbidity and multimorbidity frequently used "comorbidity" and "elderly" as MeSH keywords [7]. The reason for this may be the fact that multimorbidity is normally associated with Primary Health Care and Family Practice [53]. Many articles in the top 100 were about the prevalence of multimorbidity and the impact of chronic diseases on quality of life.

The current study has several limitations. First, since multimorbidity is a recent MeSH term, publications with the correct nomenclature will be too recent to reach a relevant number of citations. Consequently, some articles regarding comorbidity and not MM could have been inadvertently included in the top 100. Nonetheless, to reduce this possible bias, the authors chose to search only for "multimorbidity" and "multi-morbidity" and performed a subsequent article selection.

Second, all articles included in the top 100 were published in the English language. This may be because most publications were from English-speaking countries. MM research may not be reaching important non-English speaking areas of the world.

Third, there may be high quality articles published in recent years where the elapsed period of time since publication was insufficient for them to reach a number of citations equivalent to those already published for a longer period of time.

Lastly, by choosing to include only the first author, some researchers that have co-authored other articles in the top 100 may be underrepresented in the present study.

\section{Conclusions}

The current bibliometric analysis provides insights into the 100 most frequently cited articles on MM. Identification of articles that have the most academic reach and influence will assist in generating evidence-based descriptions, comparison, and visualisations of the research output on MM. All the 100 most cited articles on MM were published in English, and most of them were published after 2010 in journals with a high impact factor. The total number of citations was 19,777 (40.5\% were received within the last two years). The United Kingdom, the United States and Canada were the countries that led in publications. There was a predominance of review articles. Public Health and Health Services was the most common field of study. A limitation of this analysis, as in all bibliometric studies, but particularly in rapid increasing publication fields such as $\mathrm{MM}$, is that the current results may change in the not so-distant future, as citations will expectably increase. Further research could also be conducted to compare findings between different database, and Dimensions.

Acknowledgements. Data sourced from Dimensions, an inter-linked research information system provided by Digital Science (https://www.dimensions.ai).

Source of funding: This work was funded from the authors' own resources.

Conflicts of interest: The authors declare no conflicts of interest.

\section{References}

1. Nicholson K, Makovski TT, Griffith LE, et al. Multimorbidity and comorbidity revisited: refining the concepts for international health research. J Clin Epidemiol 2019; 105: 142-146, doi: 10.1016/j.jclinepi.2018.09.008.

2. Akker M van den, Buntinx F, Knottnerus JA. Comorbidity or multimorbidity. Eur J Gen Pract 1996; 2: 65-70.

3. Radner H, Yoshida K, Smolen JS, et al. Multimorbidity and rheumatic conditions-enhancing the concept of comorbidity. Nat Rev Rheumatol 2014; 10(4): 252-256, doi: 10.1038/nrrheum.2013.212.

4. Violan C, Foguet-Boreu Q, Flores-Mateo G, et al. Prevalence, determinants and patterns of multimorbidity in primary care: a systematic review of observational studies. PLOS ONE 2014; 9(7): e102149, doi: 10.1371/journal.pone.0102149.

5. Fortin M, Soubhi H, Hudon C, et al. Multimorbidity's many challenges. BMJ 2007; 334(7602): 1016-1017, doi: 10.1136/ bmj.39201.463819.2C.

6. Ramond-Roquin A, Fortin M. Towards increased visibility of multimorbidity research. J Comorb 2016; 6(2): 42-45, doi: 10.15256/ joc.2016.6.80

7. Catalá-López F, Alonso-Arroyo A, Page MJ, et al. Mapping of global scientific research in comorbidity and multimorbidity: a crosssectional analysis. PLOS ONE 2018; 13(1): e0189091, doi: 10.1371/journal.pone.0189091.

8. The Lancet. Making more of multimorbidity: an emerging priority. Lancet 2018; 391(10131): 1637, doi: 10.1016/S0140-6736(18)30941-3.

9. Powell AGMT, Ellul T, Bullock N, et al. Reply letter to: emergency general surgery - is there any value in a "100 most cited" list? Int J Surg 2019; 64: 54-55, doi: 10.1016/j.jisu.2019.02.003.

10. Garfield E. 100 citation classics from the Journal of the American Medical Association. JAMA 1987; 257(1): 52-59.

11. Tarazona B, Lucas-Dominguez R, Paredes-Gallardo V, et al. The 100 most-cited articles in orthodontics: a bibliometric study. Angle Orthod 2018; 88(6): 785-796, doi: 10.2319/012418-65.1.

12. Hook DW, Porter SJ, Herzog C. Dimensions: building context for search and evaluation. Front Res Metr Anal 2018; 3: 23, doi: 10.3389/ frma.2018.00023.

13. Dimensions. Why did we build Dimensions? 2019 [cited 4.08.2019]. Available from URL: https://www.dimensions.ai/why-dimensions/.

14. Barnett K, Mercer SW, Norbury M, et al. Epidemiology of multimorbidity and implications for health care, research, and medical education: a cross-sectional study. Lancet 2012; 380(9836): 37-43, doi: 10.1016/S0140-6736(12)60240-2.

15. Groot V de, Beckerman H, Lankhorst GJ, et al. How to measure comorbidity. A critical review of available methods. J Clin Epidemiol 2003; 56(3): 221-229, doi: 10.1016/s0895-4356(02)00585-1.

16. Marengoni A, Angleman S, Melis R, et al. Aging with multimorbidity: a systematic review of the literature. Ageing Res Rev 2011; 10(4): 430-439, doi: 10.1016/j.arr.2011.03.003.

17. Dumbreck S, Flynn A, Nairn M, et al. Drug-disease and drug-drug interactions: systematic examination of recommendations in 12 UK national clinical guidelines. BMJ 2015; 350: h949, doi: 10.1136/bmj.h949.

18. Wallace E, Salisbury C, Guthrie B, et al. Managing patients with multimorbidity in primary care. BMJ 2015; 350: h176, doi: 10.1136/bmj.h176.

19. Emerging Risk Factors Collaboration, Di Angelantonio E, Kaptoge S, Wormser D, et al. Association of cardiometabolic multimorbidity with mortality. JAMA 2015; 314(1): 52-60, doi: 10.1001/jama.2015.7008.

20. Coventry P, Lovell K, Dickens $C$, et al. Integrated primary care for patients with mental and physical multimorbidity: cluster randomised controlled trial of collaborative care for patients with depression comorbid with diabetes or cardiovascular disease BMJ 2015; 350: h638, doi: 10.1136/bmj.h638. 
21. Smith SM, Wallace E, O'Dowd T, et al. Interventions for improving outcomes in patients with multimorbidity in primary care and community settings. Cochrane Database Syst Rev 2016; 3(3): CD006560, doi: 10.1002/14651858.CD006560.pub3.

22. Salive ME. Multimorbidity in older adults. Epidemiol Rev 2013; 35(1): 75-83, doi: 10.1093/epirev/mxs009.

23. Salisbury C. Multimorbidity: redesigning health care for people who use it. Lancet 2012; 380(9836): 7-9, doi: 10.1016/S01406736(12)60482-6.

24. Banerjee S. Multimorbidity - older adults need health care that can count past one. Lancet 2015; 385(9968): 587-589, doi: 10.1016/ S0140-6736(14)61596-8.

25. Fortin M, Bravo G, Hudon C, et al. Prevalence of multimorbidity among adults seen in family practice. Ann Fam Med 2005; 3(3): 223-228, doi: 10.1370/afm. 272.

26. Fortin M, Lapointe L, Hudon C, et al. Multimorbidity and quality of life in primary care: a systematic review. Health Qual Life Outcomes 2004; 2: 51, doi: 10.1186/1477-7525-2-51.

27. Fortin M, Stewart M, Poitras ME, et al. A systematic review of prevalence studies on multimorbidity: toward a more uniform methodology. Ann Fam Med 2012; 10(2): 142-151, doi: 10.1370/afm.1337.

28. Fortin M, Bravo G, Hudon C, et al. Relationship between multimorbidity and health-related quality of life of patients in primary care. Qual Life Res 2006; 15(1): 83-91, doi: 10.1007/s11136-005-8661-z.

29. Fortin M, Hudon C, Haggerty J, et al. Prevalence estimates of multimorbidity: a comparative study of two sources. BMC Health Serv Res 2010; 10: 111, doi:10.1186/1472-6963-10-111.

30. Fortin M, Lapointe L, Hudon C, et al. Multimorbidity is common to family practice: is it commonly researched? Can Fam Physician 2005; 51(2): 244-245.

31. Fortin M, Bravo G, Hudon C, et al. Psychological distress and multimorbidity in primary care. Ann Fam Med 2006; 4(5): 417-422, doi: 10.1370/afm.528.

32. Fortin M, Dubois MF, Hudon C, et al. Multimorbidity and quality of life: a closer look. Health Qual Life Outcomes 2007; 5: 52, doi: 10.1186/1477-7525-5-52.

33. Fortin M, Hudon C, Dubois MF, et al. Comparative assessment of three different indices of multimorbidity for studies on health-related quality of life. Health Qual Life Outcomes 2005; 3: 74, doi: 10.1186/1477-7525-3-74.

34. Marengoni A, Winblad B, Karp A, et al. Prevalence of chronic diseases and multimorbidity among the elderly population in Sweden. Am J Public Health 2008; 98(7): 1198-1200, doi: 10.2105/AJPH.2007.121137.

35. Marengoni A, Rizzuto D, Wang HX, et al. Patterns of chronic multimorbidity in the elderly population. J Am Geriatr Soc 2009; 57(2): 225-230, doi: 10.1111/j.1532-5415.2008.02109.x.

36. Marengoni A, Strauss E von, Rizzuto D, et al. The impact of chronic multimorbidity and disability on functional decline and survival in elderly persons. A community-based, longitudinal study. J Intern Med 2009; 265(2): 288-295, doi: 10.1111/j.1365-2796.2008.02017.x.

37. Bayliss EA, Edwards AE, Steiner JF, et al. Processes of care desired by elderly patients with multimorbidities. Fam Pract 2008; 25(4): 287-293, doi: 10.1093/fampra/cmn040.

38. Bayliss EA, Ellis JL, Steiner JF. Barriers to self-management and quality-of-life outcomes in seniors with multimorbidities. Ann Fam Med 2007; 5(5): 395-402, doi: 10.1370/afm.722.

39. Bayliss EA, Ellis JL, Steiner JF. Seniors' self-reported multimorbidity captured biopsychosocial factors not incorporated into two other data-based morbidity measures. J Clin Epidemiol 2009; 62(5): 550-557.e1, doi: 10.1016/j.jclinepi.2008.05.002.

40. Akker M van den, Buntinx F, Metsemakers JF, et al. Multimorbidity in general practice: prevalence, incidence, and determinants of cooccurring chronic and recurrent diseases. J Clin Epidemiol 1998; 51(5): 367-375, doi: 10.1016/s0895-4356(97)00306-5.

41. Akker M van den, Buntinx F, Roos S, et al. Problems in determining occurrence rates of multimorbidity. J Clin Epidemiol 2001; 54(7): 675-679, doi: 10.1016/s0895-4356(00)00358-9.

42. Heldwein FL, Rhoden EL, Morgentaler A. Classics of urology: a half century history of the most frequently cited articles (1955-2009). Urology 2010; 75(6): 1261-1268, doi: 10.1016/j.urology.2009.09.043.

43. Powell AGMT, Bevan V, Brown C, et al. Altmetric versus bibliometric perspective regarding publication impact and force. World J Surg 2018; 42(9): 2745-2756, doi: 10.1007/s00268-018-4579-9.

44. Tardy C. The role of english in scientific communication: lingua franca or Tyrannosaurus rex? J Engl Acad Purp 2004; 3: 247-269, doi: 10.1016/j.jeap.2003.10.001.

45. Weijen D, van. The language of (future) scientific communication. Research Trends 2012 Nov [cited 30.07.2019]. Available from URL: https://www.researchtrends.com/issue-31-november-2012/the-language-of-future-scientific-communication/.

46. Tollefson J. China declared world's largest producer of scientific articles. Nature 2018; 553(7689): 390, doi: 10.1038/d41586-01800927-4.

47. López-Navarro I, Moreno Al, Quintanilla MÁ, et al. Why do I publish research articles in english instead of my own language? Differences in spanish researchers' motivations across scientific domains. Scientometrics 2015; 103: 939-976, doi: 10.1007/s11192-015-1570-1.

48. Credit where credit is due. Nature 2009; 462(7275): 825, doi: 10.1038/462825a.

49. Silobrcic V. How to increase the impact factor of a scientific journal? Donald Sch J Ultrasound Obstetrics Gynecology 2015; 9: 357-360, doi: 10.5005/jp-journals-10009-1422.

50. Ioannidis JP, Boyack K, Wouters PF. Citation metrics: a primer on how (not) to normalize. PLoS BIOL 2016; 14(9): e1002542, doi: 10.1371/journal.pbio.1002542.

51. Ioannidis JP. Concentration of the most-cited papers in the scientific literature: analysis of journal ecosystems. PLOS ONE 2006; 1(1): e5, doi: 10.1371/journal.pone.0000005.

52. Callaham M, Wears RL, Weber E. Journal prestige, publication bias, and other characteristics associated with citation of published studies in peer-reviewed journals. JAMA 2002; 287(21): 2847-2850, doi: 10.1001/jama.287.21.2847.

53. Valderas JM, Starfield B, Sibbald B, et al. Defining comorbidity: implications for understanding health and health services. Ann Fam Med 2009; 7(4): 357-363, doi: 10.1370/afm.983.

Tables: 2

Figures: 3

References: 53

Received: 1.04 .2020

Reviewed: 24.05.2020

Accepted: 15.10 .2020
Address for correspondence:

Prof. Filipe Prazeres

Faculdade de Ciências da Saúde

Universidade da Beira Interior

6200-506 Covilhã

Portugal

Tel.: +351 234393150

E-mail: filipeprazeresmd@gmail.com 